\title{
Nitrogen dynamics in a Latosol cultivated with coffee
}

\author{
José A. Souza ${ }^{1}$, Genelício C. Rocha ${ }^{1}$, Mateus de P. Gomes ${ }^{1}$ \& Carlos H. S. Rezende $^{1}$ \\ ${ }^{1}$ Universidade Federal de Viçosa/Departamento de Solos. Viçosa, MG. E-mail: adinansouza@yahoo.com.br - ORCID: 0000-0001-7204-4836; \\ genelicio@yahoo.com.br - ORCID: 0000-0003-0093-7517; mateusgomes2006@yahoo.com.br (Corresponding author) - ORCID: 0000-0001- \\ 7783-0799; phn.carlos@gmail.com - ORCID: 0000-0002-1465-8722
}

\section{Key words:}

NBPT

urea

nitrate flow

\begin{abstract}
A B S T R A C T
The objective of this study was to evaluate nitrogen losses by $\mathrm{NH}_{3}$ volatilization and quantify the upward and downward $\mathrm{NO}_{3}{ }^{-}$flows in Latosol cultivated with arabica coffee. An experiment was set in 2010, in Viçosa-M ${ }^{3}$, Brazil $\left(20^{\circ} 41^{\prime} \mathrm{S}\right.$ and $\left.42^{\circ} 48^{\prime} \mathrm{W}\right)$, in a randomized block design in a ( $3 \times 2)+1$ factorial arrangement with three nitrogen doses $(200,400$ and $600 \mathrm{~kg} \mathrm{ha}^{-1}$ ), two forms of urea (conventional and NBPT urease inhibitor-treated) and one additional treatment without nitrogen fertilization, with four replicates. Semi-open type chambers were installed to quantify $\mathrm{NH}_{3}$ volatilization. To determine the concentration and flow of $\mathrm{NO}_{3}{ }^{-}$a soil solution extractor was installed in each plot at a 1-m depth together with three tensiometers at depths of $0.90,1.00$ and $1.10 \mathrm{~m}$. Nitrogen losses by volatilization were 3.51 and $11.21 \%$ for NBPT-treated urea and conventional urea, respectively. The rainfall $(1172 \mathrm{~mm})$, its distribution and the dose strongly influenced the losses by leaching. Urease inhibitor-treated urea led to higher risk of groundwater contamination with $\mathrm{NO}_{3}^{-}$. Returns of $\mathrm{NO}_{3}^{-}$occur in periods of drought, but it is not possible to state if this $\mathrm{NO}_{3}^{-}$can be used by the plant because, under these conditions, the soil has low moisture content, which may compromise the absorption.
\end{abstract}

\section{Palavras-chave: \\ NBPT \\ ureia \\ fluxo de nitrato}

\section{Dinâmica do nitrogênio em Latossolo cultivado com café}

\section{R E S U M O}

Objetivou-se no estudo avaliar as perdas de nitrogênio por volatilização de $\mathrm{NH}_{3}$ e quantificar os fluxos ascendentes e descendentes de $\mathrm{NO}_{3}^{-}$em Latossolo cultivado com café arábica. Para isso, montou-se um experimento no ano de 2010, na cidade de Viçosa, MG, coordenadas geográficas $20^{\circ} 41^{\prime} \mathrm{S}$ e $42^{\circ} 48^{\prime} \mathrm{O}$. Utilizou-se delineamento em blocos ao acaso em fatorial (3 $\mathrm{x} 2)+1$, sendo três doses de $\mathrm{N}\left(200,400,600 \mathrm{~kg} \mathrm{ha}^{-1}\right)$, duas formas de ureia (convencional e tratada com NBPT) e um tratamento adicional sem adubação nitrogenada, com quatro repetições. Foram instaladas câmaras do tipo semiabertas para quantificar a volatilização de $\mathrm{NH}_{3}$. Para determinar a concentração e o fluxo de $\mathrm{NO}_{3}$ - foram instalados em cada parcela, um extrator de solução do solo na profundidade de $1 \mathrm{~m}$, juntamente com três tensiômetros às profundidades de 0,$90 ; 1,00$ e $1,10 \mathrm{~m}$. As perdas de $\mathrm{N}$ por volatilização foram de $3,51 \mathrm{e}$ $11,21 \%$ para a ureia com NBPT e ureia comum, respectivamente. A precipitação $(1172 \mathrm{~mm})$, a distribuição das chuvas e a dose influenciaram fortemente nas perdas por lixiviação. A ureia tratada com inibidor apresentou maior risco de contaminação das águas subterrâneas com $\mathrm{NO}_{3}^{-}$. Há um retorno do $\mathrm{NO}_{3}^{-}$em períodos de seca, mas não é possível dizer se este $\mathrm{NO}_{3}{ }_{3}^{-}$pode ser usado pela planta, pois nessas condições, o solo tem baixo teor de umidade, o que pode comprometer a absorção. 


\section{INTRODUCTION}

Urea corresponds to $60 \%$ of the nitrogen fertilizers used in the Brazilian agriculture, due to its lower cost per unit of nitrogen (N) applied. Nevertheless, it has limitations with respect to superficial application, due to the high losses through ammonia $\left(\mathrm{NH}_{3}\right)$ volatilization. In this case, using urease inhibitors is an efficient alternative to reduce the losses through $\mathrm{NH}_{3}$ volatilization and increase $\mathrm{N}$ use efficiency (Soares et al., 2012).

In order to meet this demand, the industry has developed more efficient $\mathrm{N}$ fertilizers. Among the fertilizers commercialized, those treated with $\mathrm{N}$-(N-butyl) thiophosphoric triamide (NBPT) have shown the best results (Abalos et al., 2014).

NBPT has proven to be efficient at reducing ammonia volatilization and, consequently, the losses of $\mathrm{N}$ applied through urea. However, these results depend on the management adopted for each crop (Tasca et al., 2011). In addition, the compound may indirectly influence $\mathrm{N}$ loss through nitrate $\left(\mathrm{NO}_{3}^{-}\right)$leaching, since it reduces the speed of transformation of amidic $\mathrm{N}$ into ammoniacal $\mathrm{N}$, but it does not interfere with ammonium nitrification.

Given the above, this study aimed to evaluate $\mathrm{N}$ losses through $\mathrm{NH}_{3}$ volatilization and quantify upward and downward $\mathrm{NO}_{3}$ - flows in Latosol cultivated with coffee (Coffea arabica L.), fertilized with conventional urea and NBPT-treated urea.

\section{Material ANd Methods}

The experiment was carried out in 2010, at the Laje Farm, a coffee farm typical of the Zona da Mata in Minas Gerais ( $\left.20^{\circ} 41^{\prime} \mathrm{S} ; 42^{\circ} 48^{\prime} \mathrm{W}\right)$. The region has Cwb climate according to Köppen's classification, humid temperate with dry winter and hot summer.

The results of the granulometric analysis, obtained by the pipette method (Ruiz, 2005), indicated that the soil in the experimental area has approximately $510 \mathrm{~g} \mathrm{~kg}^{-1}$ of clay, $340 \mathrm{~g} \mathrm{~kg}^{-1}$ of sand and $150 \mathrm{~g} \mathrm{~kg}^{-1}$ of silt, in the $0-0.1 \mathrm{~m}$ layer, and the values remained virtually unchanged until the $1.10 \mathrm{~m}$ depth.

The experimental design was randomized blocks, in $(3 \mathrm{x}$ 2) +1 factorial arrangement corresponding to three $\mathrm{N}$ doses $\left(200,400\right.$ and $\left.600 \mathrm{~kg} \mathrm{ha}^{-1}\right)$, two forms of urea (both with $45 \% \mathrm{~N}$ : conventional and with NBPT urease inhibitor), one additional treatment without $\mathrm{N}$ application, and four replicates, totaling 28 plots.

Each plot was composed of 18 plants and the two central plants were used for evaluation. $\mathrm{N}$ fertilization was split into three applications, following the period commonly considered by the farmer; the first application occurred on December 10, 2010, the second on January 4, 2011, and the third on February 1,2011 . A pluviometer was installed close to the experimental area, to quantify the entry of water through rainfall.

To quantify the losses through ammonia volatilization, a semi-open ammonia collector made of PVC cylinder $(0.20 \mathrm{~m}$ diameter and $0.40 \mathrm{~m}$ height) was installed in each plot close to the plant (Figure 1).

The $\mathrm{NH}_{3}$-capture unit was a 0.15 -m-diameter disc of Nylon foam $\left(\mathrm{d}=2.4 \mathrm{~kg} \mathrm{~m}^{-3}\right)$, soaked with $25 \mathrm{~mL}$ of $1 \mathrm{~mol} \mathrm{~L}^{-1}$

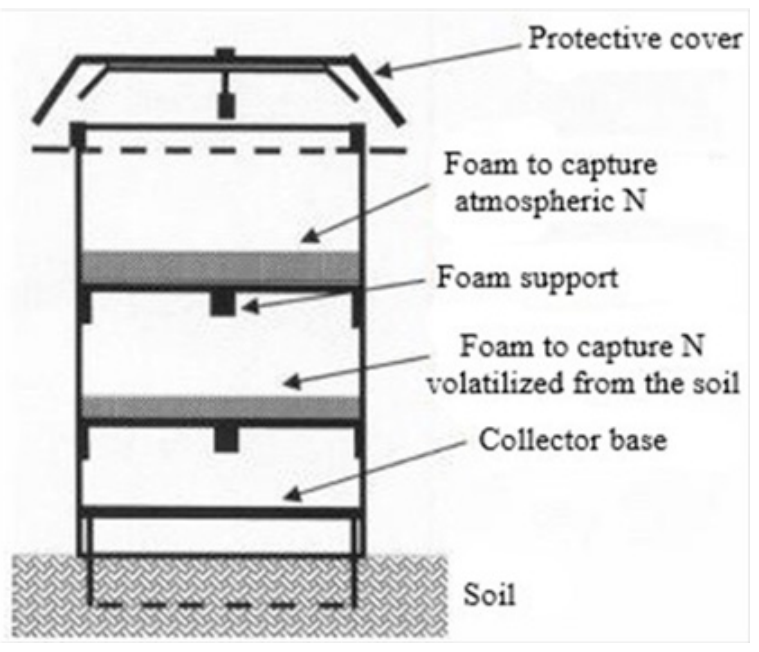

Source: Duarte et al. (2007)

Figure 1. Scheme of the semi-open collectors used to collect volatilized ammonia

$\mathrm{H}_{2} \mathrm{SO}_{4}+30 \mathrm{~g} \mathrm{~L}^{-1}$ glycerin solution. The $\mathrm{NH}_{3}$-capture unit was installed inside the collector, fixed by a PVC support at 0.15 $\mathrm{cm}$ height above the soil.

Another disc of the same Nylon foam ( $0.20 \mathrm{~m}$ diameter) was installed $0.10 \mathrm{~m}$ below the top end of the collector, also soaked in $\mathrm{H}_{2} \mathrm{SO}_{4}+$ glycerin solution, to avoid contamination of the $\mathrm{NH}_{3}$-capture unit by $\mathrm{NH}_{3}$ from the external atmosphere.

Covers suspended by wire rods were installed above the collectors to allow air circulation. The collector was attached to a base made of PVC cylinder with the same diameter and $0.15 \mathrm{~m}$ height, inserted into the soil up to $0.05 \mathrm{~m}$ deep.

Three bases were installed in each plot, as described above, which received fertilization according to the doses established. The collecting foams were installed immediately after fertilization. The first change of foam occurred 4 days after fertilization, whereas the others occurred every 7 days, totaling four changes of foam in each one of the three periods of fertilization.

For $\mathrm{NH}_{3}$ determination, the foams were washed in $1 \mathrm{~mol} \mathrm{~L}^{-1}$ $\mathrm{KCl}$ solution and then cut into small pieces. The obtained solution and foam pieces were transferred to test tubes, which were attached to the Kjeldahl distiller for distillation.

One solution extractor and three tensiometers were installed in each plot. The tensiometers were installed $0.60 \mathrm{~m}$ away from the soil solution extractor, at depths of $0.90,1.00$ and $1.10 \mathrm{~m}$, attached to a mercury manometer to calculate the water flow according to the Darcy-Buckingham equation (Libardi, 2005).

After obtaining soil water flow, nitrate flow was estimated using the methodology proposed by Fernandes et al. (2006). Soil solution extractors were installed at $1 \mathrm{~m}$ depth and the solution was collected using a syringe (Fernandes et al., 2006).

Collections were always carried out after rains greater than $2 \mathrm{~mm}$, within at most $24 \mathrm{~h}$ after the rainfall event. The collected solution was transferred to inert, opaque plastic containers and maintained in the fridge until $\mathrm{NO}_{3}$ -N determination, performed by steam distillation using Devarda's alloy.

Unsaturated soil hydraulic conductivity $K(\theta)$ was obtained by the soil-water retention curve (Mualem, 1976). To generate 
the soil-water retention curve, undisturbed soil samples were taken to tension table to determine the equilibrium moisture at tensions of 2, 4, 6 and $8 \mathrm{kPa}$. The other points of the curve were determined using disturbed samples in Richards apparatus at tensions of 10, 30, 100, 500, 1000 and $1500 \mathrm{kPa}$, totaling 10 points in each curve.

The data were subjected to analysis of variance in the program Statistical Analysis System - SAS. Then the program Table curve $2 \mathrm{D}$ was used to obtain the regression models according to the applied doses.

\section{Results AND Discussion}

In the coffee crop, ammonia volatilization may result in losses higher than $30 \%$ of the $\mathrm{N}$ applied through urea (Dominghetti et al., 2016). In the present study, $\mathrm{N}$ losses through $\mathrm{NH}_{3}$ volatilization were higher for conventional urea compared with NBPT-treated urea (Figure 2A). However, the proportion of $\mathrm{N}$ lost in relation to the dose did not change, showing mean values of 11.21 and $3.51 \%$ for conventional urea and NBPT-treated urea, respectively. Scivittaro et al. (2010), studying losses through ammonia volatilization in the rice crop, observed percentage losses varying from 15 to $22 \%$ using conventional urea and from 2.55 to $9.55 \%$ using NBPT-treated urea.

The percentage losses of the applied $\mathrm{N}$ vary according to the environmental conditions and are maximized under adverse conditions such as: when the fertilized is applied on straw in wet soil with high $\mathrm{pH}$, high temperatures, in a site with occurrence of winds and without prospect of rains and high doses of urea (Malhi et al., 2001). In these cases, using urease inhibitor is highly recommended (Abalos et al., 2014), due to the high potential of losses of the $\mathrm{N}$ applied, which may exceed 70\% (Lara Cabezas et al., 1997).

$\mathrm{NH}_{3}$ losses showed more accentuated peaks on the fourth day after $\mathrm{N}$ fertilizer application (Figures $2 \mathrm{~B}$ ). $\mathrm{NH}_{3}$ volatilization is influenced by edaphoclimatic conditions; thus, there were variations in the periods of occurrence of volatilization peaks. There are reports of volatilization peaks occurring on the second day after fertilization (Stafanato et al., 2013), on the fourth day after fertilization (Lara Cabezas et al., 1997) and between the seventh and eighth days after fertilization (Lanna et al., 2010).

Urease inhibitor-treated urea showed peaks with lower amplitudes compared with those of conventional urea. In addition, the curves demonstrated that $\mathrm{NH}_{3}$ volatilization from urease inhibitor-treated urea takes a longer time, but with lower intensity. This fact becomes more evident especially in the curves of the second and third fertilizations and for the highest doses (Figures $2 \mathrm{~B}$ and $\mathrm{C}$ ), which suggest residual effect of NBPT because, at 61 days, there was almost no $\mathrm{NH}_{3}$ volatilization from conventional urea, whereas volatilization occurred for NBPT-treated urea, especially at the dose of $600 \mathrm{~kg} \mathrm{ha}^{-1}$.

NBPT stability in the soil depends on temperature and moisture, varying from 3 to 15 days. Nevertheless, in the present study, fertilization was applied below the coffee canopy
A.

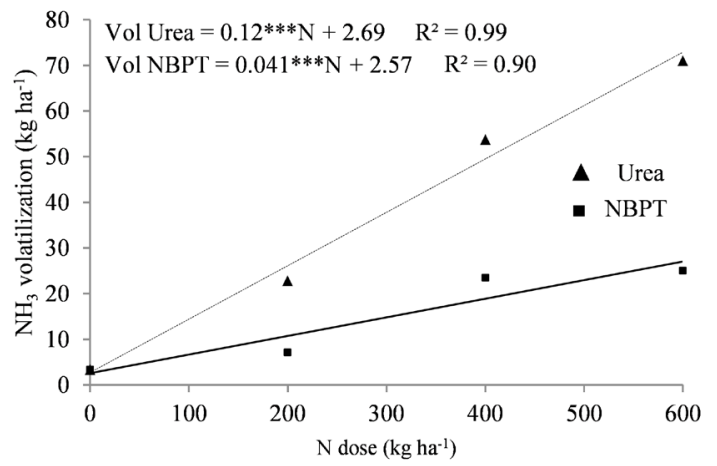

B.

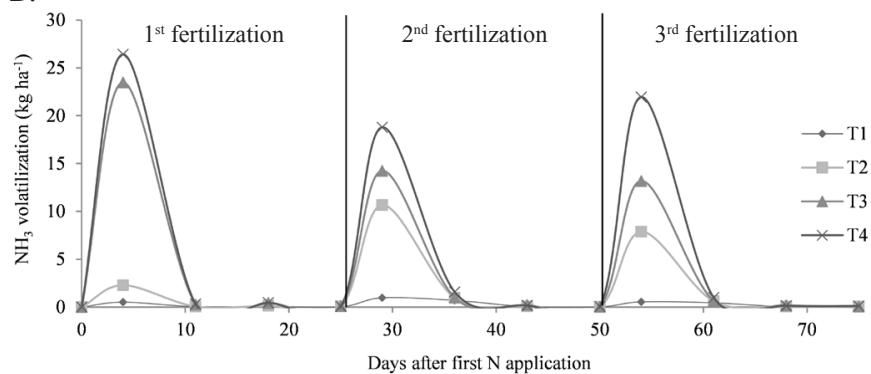

C.

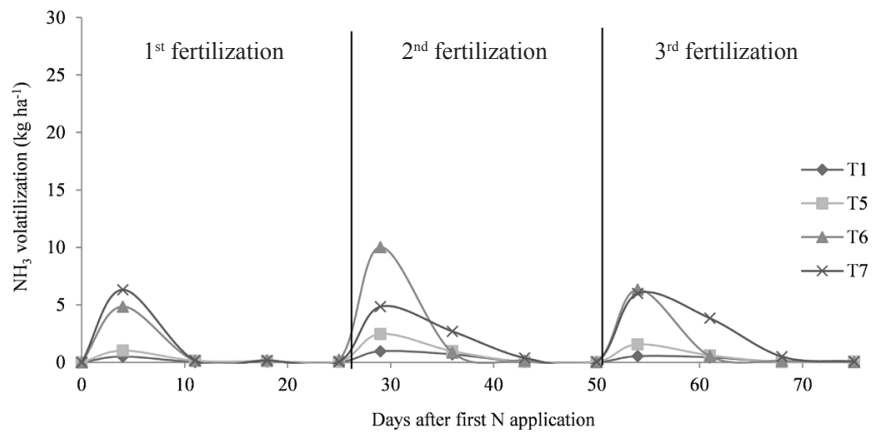

*** Significant at 0.001 probability level by t-test

Figure 2. $\mathrm{NH}_{3}$ volatilization as a function of the $\mathrm{N}$ dose applied in the form of urea and NBPT-treated urea (A); $\mathrm{NH}_{3}$ volatilization for T1 $=0 \mathrm{~kg} \mathrm{ha}^{-1}$ of $\mathrm{N} ; \mathrm{T} 2, \mathrm{~T} 3$ and $\mathrm{T} 4$ $=200,400$ and $600 \mathrm{~kg} \mathrm{ha}^{-1}$ of $\mathrm{N}$, respectively, applied through urea (B); $\mathrm{NH}_{3}$ volatilization for T5, T6 and T7 $=200,400$ and $600 \mathrm{~kg} \mathrm{ha}^{-1}$ of $\mathrm{N}$, respectively, applied through NBPT-treated urea $(\mathrm{C})$

projection, where the microclimate may have contributed to maintaining the NBPT in the soil, delaying its period of action. The microclimate formed by the coffee crown also contributes to reducing $\mathrm{N}$ losses through $\mathrm{NH}_{3}$ volatilization, since lower temperatures along with the reduction in the occurrence of winds are unfavorable to urease action and ammonia movement from the soil to the atmosphere.

There were rainfalls of $90 \mathrm{~mm}$ on the fifth day after the first fertilization, of $54 \mathrm{~mm}$ on the fourth day after the second fertilization and of 10 and $20 \mathrm{~mm}$ on the first and ninth days after the third fertilization, respectively. The rain volume necessary for fertilizer incorporation, after application, varies according to the type of soil and application conditions. In conventional plantations, 10 to $20 \mathrm{~mm}$ are considered as sufficient to incorporate urea and reduce or even eliminate $\mathrm{NH}_{3}$ losses (Hargrove, 1988). However, when it is applied on straw, the rain volume necessary to incorporate the applied $\mathrm{N}$ must be higher. 
Higher peaks of ammonia volatilization were observed in the first fertilization $\left(23.5 \mathrm{~kg} \mathrm{ha}^{-1}\right.$ of $\mathrm{NH}_{3}$ in $\mathrm{T} 3$ and $26.4 \mathrm{~kg} \mathrm{ha}^{-1}$ of $\mathrm{NH}_{3}$ in $\mathrm{T} 4$ ), probably because the rainfall only occurred five days after fertilization (Figure 2B).

Soil moistening immediately after urea application is more important in the reduction of ammonia losses than the soil moisture condition at the moment of the application, especially when urea is applied on surface, without incorporation to the soil (Lara Cabezas et al., 1997). The occurrence of rains in the period from three to seven days after fertilizer application enhances the action of the inhibitor, for incorporating urea to the soil, favoring the reduction in N loss (Okumura \& Mariano,
2012). However, when NBPT is used, even with absence of rains, it is possible to obtain reduction in $\mathrm{NH}_{3}$ volatilization (Cantarella, 2007).

Nitrate flow in the soil (Figure 3) is strongly influenced by rainfall. It can be inferred that the intensification of nitrate leaching is also associated with the dry spells.

It is noted that nitrate flow was low during the first 30 days, but abrupt peaks occurred between 30 and 50 days. In the saturated soil, oxygen activity is low, which limits nitrification. On the other hand, as the soil dried, from 28 and 37 days, there was an increase in oxygen activity, which favored the oxidation of $\mathrm{NH}_{4}^{+}$to $\mathrm{NO}_{3}^{-}$.

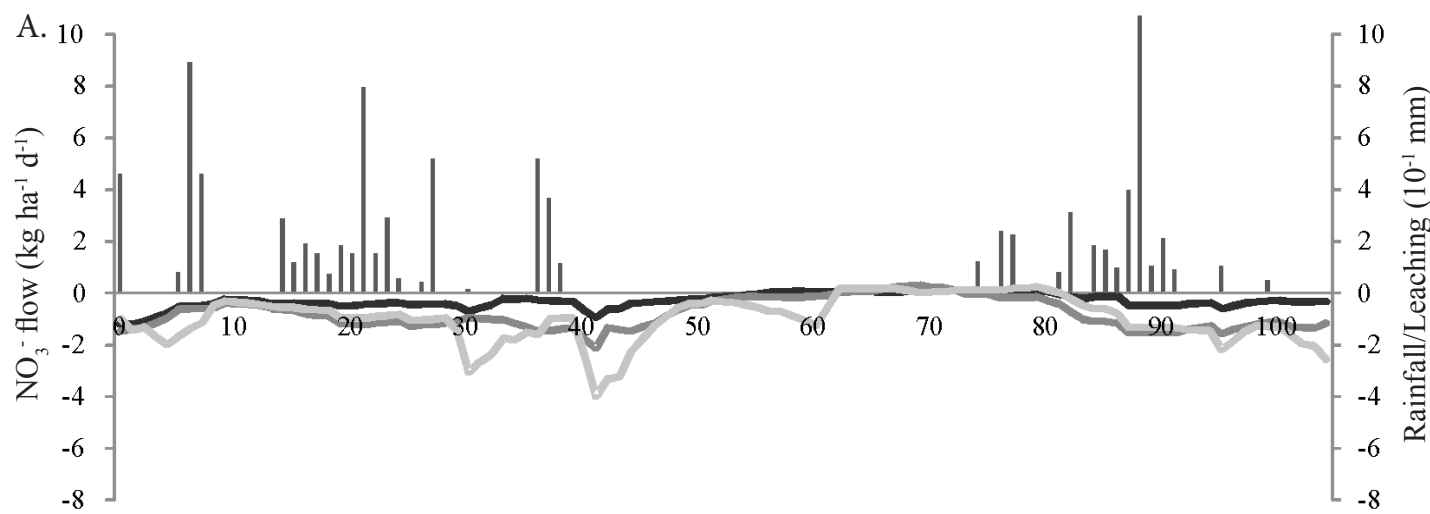

Days after the experiment started

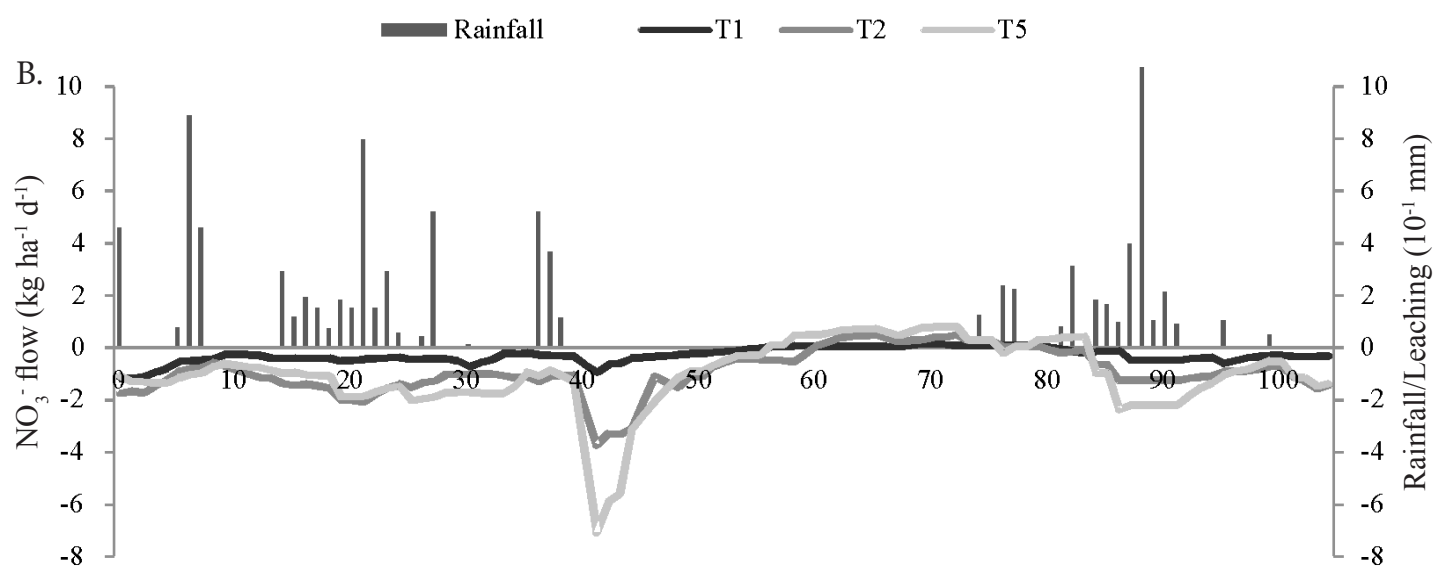

Days after the experiment started

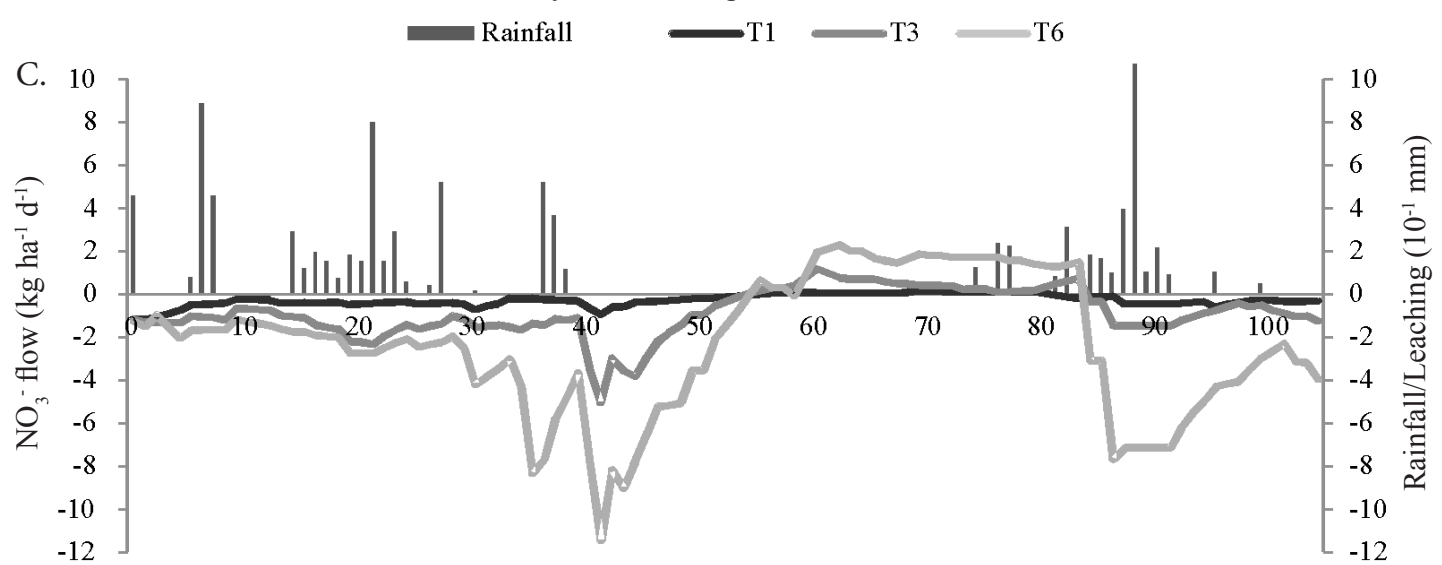

Days after the experiment started

$$
\text { Rainfall } \quad-\mathrm{T} 1=\mathrm{T} 4=\mathrm{T} 7
$$

Figure 3. Nitrate flow in the soil along the experiment: $\mathrm{T} 1=0 \mathrm{~kg} \mathrm{ha}^{-1}$ of $\mathrm{N}, \mathrm{T} 2$ and $\mathrm{T} 5=200 \mathrm{~kg} \mathrm{ha}^{-1}$ of $\mathrm{N}$ for conventional urea and NBPT-treated urea, respectively (A); T1 $=0 \mathrm{~kg} \mathrm{ha}^{-1}$ of N, T3 and T6 $=400 \mathrm{~kg} \mathrm{ha}^{-1}$ of N for conventional urea and NBPT-treated urea, respectively $(\mathrm{B}) ; \mathrm{T} 1=0 \mathrm{~kg} \mathrm{ha}^{-1}$ of $\mathrm{N}, \mathrm{T} 4$ and $\mathrm{T} 7=600 \mathrm{~kg} \mathrm{ha}^{-1}$ of $\mathrm{N}$, for conventional urea and NBPT-treated urea, respectively $(\mathrm{C})$ 
Nitrate leaching in subsurface is hampered in highly weathered soils with high contents of iron and aluminum oxides, because these minerals have high PZC, contributing to increasing the positive charges in the soil, which would retain nitrate.

The present study was conducted in soils of built-up fertility, in which successive agricultural practices such as liming, gypsum application and fertilization amended the soil profile. Under these conditions, soil positive charges are neutralized so that nitrate finds no resistance to flow (Barton et al., 2006; Rodrigues et al., 2007).

After a 4-day period without rains (days 32 and 43), the flow is reversed, probably due to the crop evapotranspiration. Crop evapotranspiration promotes a reduction of soil moisture in the surface layers, leading to an inversion in the sign of the Darcy's equation, characterizing an upward flow of soil solution (Libardi, 2005).

$\mathrm{NO}_{3}{ }^{-}$flow variation along the experiment was similar for all doses applied, showing higher intensity at the highest doses. Higher $\mathrm{NO}_{3}$ - concentrations have direct influence on the flow. $\mathrm{NO}_{3}{ }^{-}$flow was observed in $\mathrm{T} 1$ (control treatment), because the experiment was installed in a commercial area, which thus had been fertilized with $\mathrm{N}$ fertilizers over the years.

$\mathrm{NO}_{3}$ - fitted to linear models for both fertilizers. The losses through $\mathrm{NO}_{3}^{-}$leaching were higher for NBPT-treated urea than for conventional urea (Figure 4A).

Comparing the models fitted to the $\mathrm{NO}_{3}^{-}$losses through leaching as a function of the source, it was observed that at doses lower than $200 \mathrm{~kg} \mathrm{ha}^{-1}$ the risk of $\mathrm{N}$ loss and water table contamination by $\mathrm{NO}_{3}^{-}$would be similar between urease inhibitor-treated urea and conventional urea; however, for

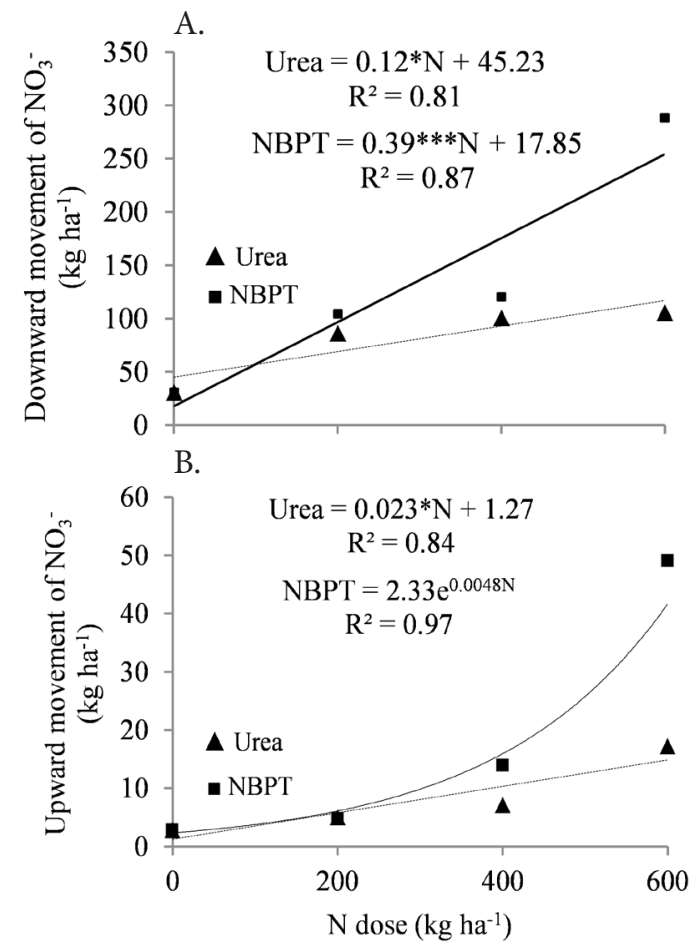

*; ${ }^{* * *}$ Significant at 0.05 and 0.001 probability levels, respectively, by t-test

Figure 4. Downward (A) and upward (B) movements of $\mathrm{NO}_{3}^{-}$as a function of the $\mathrm{N}$ dose, for conventional urea and NBPT-treated urea higher doses, the use of inhibitor caused significantly higher losses, reaching the extreme value at the $\mathrm{N}$ dose of $600 \mathrm{~kg} \mathrm{ha}^{-1}$.

According to the data obtained in the present study, there was return of $\mathrm{NO}_{3}$; i.e., inversion in the flow of the soil solution, being directly proportional to the applied dose (Figure 4B). However, it was not possible to identify if the return could be used by the plant because, under these conditions, the soil has low moisture content, which may compromise the absorption.

\section{Conclusions}

1. Conventional urea and NBPT-treated urea showed losses through volatilization of 11.21 and $3.51 \%$, respectively.

2. The use of NBPT-treated urea led to higher losses through leaching compared with conventional urea, especially at the highest doses.

3. Nitrate upward (capillary rise) and downward (leaching) movements are higher when NBPT-treated urea is used, compared with conventional urea, which demonstrates greater mobility of the nitrate from urea treated with NBPT urease inhibitor and lower mobility of the nitrate from conventional urea.

\section{Literature Cited}

Abalos, D.; Jeffery, S.; Sanz-Cobena, A.; Guardia, G.; Vallejo, A. Metaanalysis of the effect of urease and nitrification inhibitors on crop productivity and nitrogen use efficiency. Agriculture, Ecosystems \& Environment, v.189, p.136-144, 2014. https://doi.org/10.1016/j. agee.2014.03.036

Barton, L.; Wan, G. G. Y.; Colmer, T. D. Turfgrass (Cynodon dactylon L.) sod production on sandy soils: II. Effects of irrigation and fertiliser regimes on N leaching. Plant and Soil, v.284, p.147-164, 2006. https://doi.org/10.1007/s11104-006-0036-X

Cantarella, H. Nitrogênio. In: Novais R. F.; Alvarez V., V. H.; Barros, N. F.; Fontes, R. L. F.; Cantarutti, R. B.; Lima, J. C. (ed.). Fertilidade do solo. Viçosa: Sociedade Brasileira de Ciência do Solo, 2007. Cap.7, p.375-470.

Dominghetti, A. W.; Guelfi, D. R.; Guimarães, R. J.; Caputo, A. L. C.; Spehar, C. R.; Faquin, V. Nitrogen loss by volatilization of nitrogen fertilizers applied to coffee orchard. Ciência e Agrotecnologia, v.40, p.173-183, 2016. https://doi.org/10.1590/141370542016402029615

Duarte, F. M.; Pocojeski, E.; Silva, L. S. da; Graupe, F. A.; Britzke, D. Perdas de nitrogênio por volatilização de amônia com aplicação de uréia em solo de várzea com diferentes níveis de umidade. Ciência Rural, v.37, p.705-711, 2007. https://doi.org/10.1590/ S0103-84782007000300016

Fernandes, F. C. S.; Libardi, P. L.; Carvalho, L. A. de. Internal drainage and nitrate leaching in corn-black oat-corn succession with two split nitrogen applications. Scientia Agricola, v.63, p.483-492, 2006. https://doi.org/10.1590/S0103-90162006000500011

Hargrove, W. L. Soil, environmental, and management factors influencing ammonia volatilization under field conditions. In: Bock, B. R.; Kissel, D. E. (ed.). Ammonia volatilization from urea fertilizers. Alabama: National Fertilizer Development Center Tenessee Valley Authority-Muscle Shoals, 1988. Chap.2, p.17-36. 
Lanna, A. C.; Silveira, P. M. da; Silva, M. B. da; Ferraresi, T. M.; Kliemann, H. J. Urease activity as influenced by planting system and plant cover in soil under common bean. Revista Brasileira de Ciência do Solo, v.34, p.1933-1939, 2010. https://doi.org/10.1590/ S0100-06832010000600018

Lara Cabezas, W. A. R.; Korndörfer, G. H.; Motta, S. A. Volatilização de $\mathrm{N}_{-} \mathrm{NH}_{3}$ na cultura de milho: II. Avaliação de fontes sólidas e fluidas em sistema de plantio direto e convencional. Revista Brasileira de Ciência do Solo, v.21, p.489-496, 1997. https://doi. org/10.1590/S0100-06831997000300019

Libardi, P. L. Dinâmica da água no solo. São Paulo: Editora Universidade de São Paulo, 2005. 331p.

Malhi, S. S.; Grant, C. A.; Johnston A. M.; Gill, K. S. Nitrogen fertilization management for no-till cereal production in the Canadian great plains: A review. Soil \& Tillage Research, v.60, p.101-122, 2001. https://doi.org/10.1016/S0167-1987(01)00176-3

Mualem, Y. A new model for prediction the hydraulic conductivity of unsaturated porous media. Water Resources Research, v.12, p.513-522, 1976. https://doi.org/10.1029/WR012i003p00513

Okumura, R. S.; Mariano, D. de C. Aspectos agronômicos da ureia tratada com inibidor de urease. Ambiência, v.8, p.403-414, 2012. https://doi.org/10.5777/ambiencia.2012.02.02rb

Rodrigues, J. O.; Andrade, E. M. de; Crisóstomo, L. A.; Teixeira, A. dos S. Modelos da concentração iônica em águas subterrâneas no distrito de irrigação Baixo Acaraú. Revista Ciência Agronômica, v.38, p.360-365, 2007.
Ruiz, V. H. Incremento da exatidão da análise granulométrica do solo por meio da coleta da suspensão (silte + argila). Revista Brasileira de Ciência do Solo, v.29, p.297-300, 2005. https://doi.org/10.1590/ S0100-06832005000200015

Scivittaro, W. B.; Gonçalves, D. R. N.; Vale, M. L. C. do; Ricordi, V. G. Perdas de nitrogênio por volatilização de amônia e resposta do arroz irrigado à aplicação de ureia tratada com inibidor de urease NBPT. Ciência Rural, v.40, p.1283-1289, 2010. https://doi. org/10.1590/S0103-84782010000600007

Soares, J. R.; Cantarella, H.; Menegale, M. L. de C. Ammonia volatilization losses from surface-applied urea with urease and nitrification inhibitors. Soil Biology and Biochemistry, v.52, p.82-89, 2012. https://doi.org/10.1016/j.soilbio.2012.04.019

Stafanato, J. B.; Goulart, R. de S.; Zonta, E.; Lima, E.; Mazur, N.; Pereira, C. G.; Souza, H. N. de. Volatilização de amônia oriunda de ureia pastilhada com micronutrientes em ambiente controlado. Revista Brasileira de Ciência do Solo, v.37, p.726-732, 2013. https://doi.org/10.1590/S0100-06832013000300019

Tasca, F. A.; Ernani, P. R.; Rogeri, D. A.; Gatiboni, L. C.; Cassol, P. C. Volatilização de amônia do solo após a aplicação de ureia convencional ou com inibidor de uréase. Revista Brasileira de Ciência do Solo, v.35, p.493-502, 2011. https://doi.org/10.1590/ S0100-06832011000200018 